\title{
An approach for estimating the breach probabilities of moraine-dammed lakes in the Chinese Himalayas using remote-sensing data
}

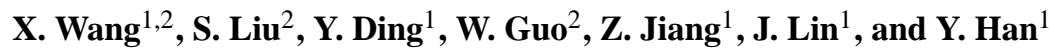 \\ ${ }^{1}$ State Key Laboratory of Cryosphere Science, Cold and Arid Regions Environmental and Engineering Research Institute, \\ CAS, Lanzhou, 730000, China \\ ${ }^{2}$ Department of Geography, Hunan University of Science \& Technology, Xiangtan, 411201, China
}

Correspondence to: X. Wang (xinwang_hn@163.com)

Received: 5 September 2011 - Revised: 24 August 2012 - Accepted: 7 September 2012 - Published: 19 October 2012

\begin{abstract}
To make first-order estimates of the probability of moraine-dammed lake outburst flood (MDLOF) and prioritize the probabilities of breaching posed by potentially dangerous moraine-dammed lakes (PDMDLs) in the Chinese Himalayas, an objective approach is presented. We first select five indicators to identify PDMDLs according to four predesigned criteria. The climatic background was regarded as the climatic precondition of the moraine-dam failure, and under different climatic preconditions, we distinguish the trigger mechanisms of MDLOFs and subdivide them into 17 possible breach modes, with each mode having three or four components; we combined the precondition, modes and components to construct a decision-making tree of moraine-dam failure. Conversion guidelines were established so as to quantify the probabilities of components of a breach mode employing the historic performance method combined with expert knowledge and experience. The region of the Chinese Himalayas was chosen as a study area where there have been frequent MDLOFs in recent decades. The results show that the breaching probabilities $(P)$ of 142 PDMDLs range from 0.037 to 0.345 , and they can be further categorized as 43 lakes with very high breach probabilities $(P \geq 0.24), 47$ lakes with high breach probabilities $(0.18 \leq P<0.24), 24$ lakes with mid-level breach probabilities $(0.12 \leq P<0.18), 24$ lakes with low breach probabilities $(0.06 \leq P<0.12)$, and four lakes with very low breach probabilities $(p<0.06)$.
\end{abstract}

\section{Introduction}

The moraine-dammed lake outburst flood (MDLOF) is a category of glacial lake outburst flood (GLOF) in which flood/debris flow is triggered by the failure of a morainedammed lake. MDLOFs endanger lives and property as well as the natural and social environment and have thus drawn much attention. Studies on MDLOFs have evaluated and simulated past MDLOF events (Lliboutry et al., 1977; Xu, 1988; Cenderelli and Wohl, 2003; Kershaw et al., 2005), modeled the magnitude and spatial extent of possible MDLOFs (Costa and Schuster, 1988; Clague and Evans, 2000; Huggel et al., 2002, 2004; Carrivick, 2006; Bajracharya et al., 2007; McKillop and Clague, 2007a; Wang et al., 2008), assessed the vulnerability of high mountain areas to the hazards of moraine-dammed lake outbursts (Carey, 2005; Vilímek et al., 2005; Hegglin and Huggel, 2008), estimated the breach probability of a moraine-dammed lake (McKillop and Clague, 2007b), and analyzed the mechanisms of a dam breach (Clague and Evans, 2000; Jiang et al., 2004; Rushmer, 2007; Balmforth et al., 2008, 2009; Awal et al., 2010). With widespread glacier retreat on the one hand and the growing population living close to high mountains on the other, there are more potentially dangerous morainedammed lakes (PDMDLs) appearing in glaciated regions (Clague and Evans, 2000; Richardson and Reynolds, 2000; Bajracharya and Mool, 2009). Engineers and geoscientists are concerned with how to estimate objectively the breach probabilities of PDMDLs.

Although many researchers have discussed factors most likely to predispose moraine dams to failure (Clague and 


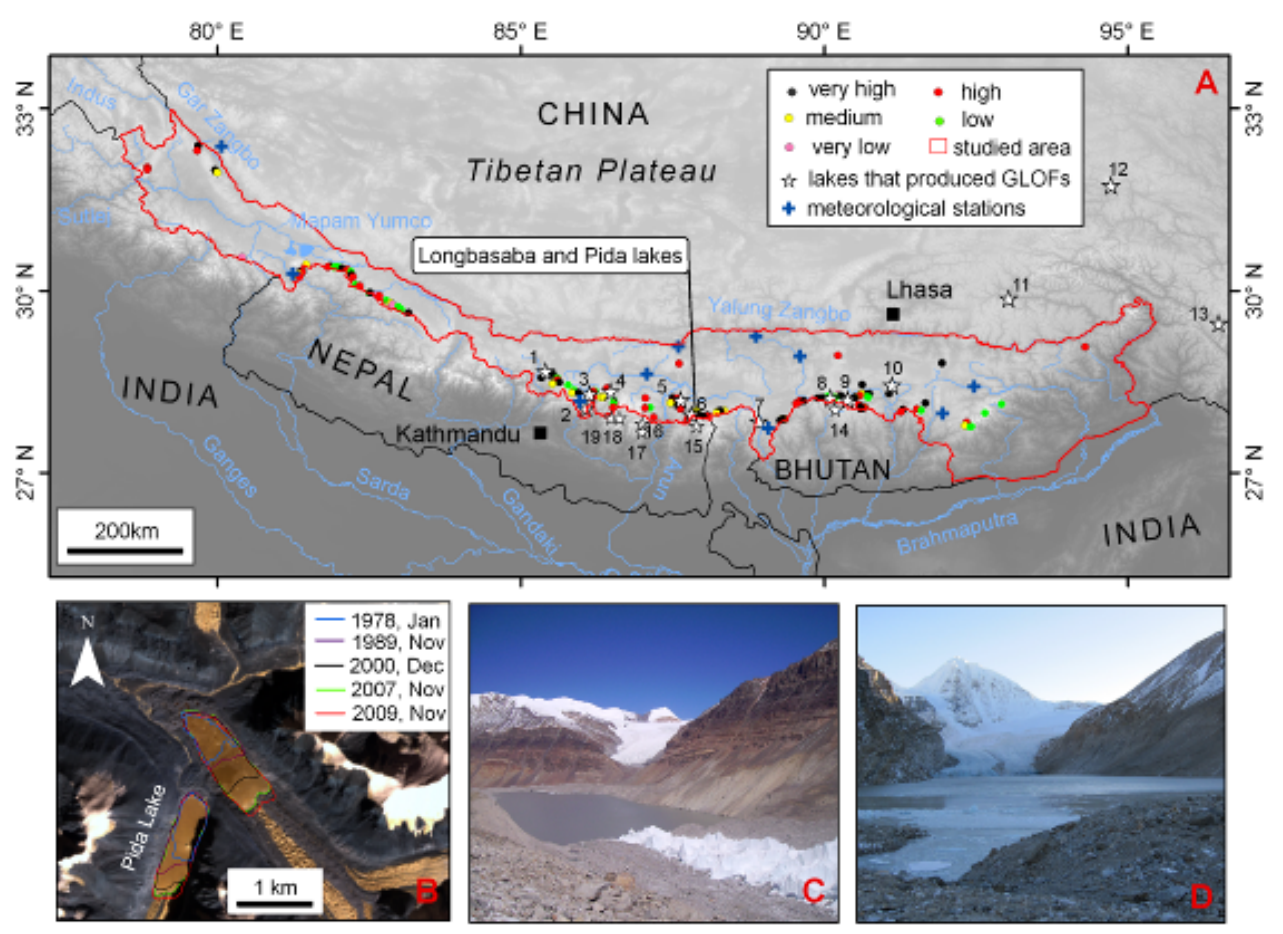

Fig. 1. (A) Distribution of different outburst probability statuses of PDMDLs in the Himalayas of China (stars indicate the MDLOF lakes in Table 2 and the identification numbers are those used in the table). (B) Expansion of two field-surveyed PDMDLs, Longbasaba and Pida Lakes, based on aerial photographs (1978), Landsat TM data (1989, 2000, and 2009), ASTER data (2007) and field survey data (2009). (C) Photograph of Longbasaba Lake taken in October 2009. (D) Photograph of Pida Lake taken in October 2009.

Evans, 2000; Richardson and Reynolds, 2000; Huggel et al., 2004; McKillop and Clague, 2007b) and the mechanisms of MDLOFs have been discussed on the basis of experimental methods and numerical simulation (Yue et al., 2008; Balmforth et al., 2008, 2009; Awal et al., 2010), there is no practicable method to calculate the outburst probability using a physical process model. Scholars have proposed appropriate indicators to qualitatively evaluate the breach probabilities of MDLOFs according to the characteristics of the morainedammed lakes. The indicators mainly involve the freeboard of the lake, moraine dam, parent glacier, lake basin settings, and climatic background (Lv et al., 1999; Huggel et al., 2004; Watanabe et al., 2009; Janský et al., 2010). In recent years, much progress has been made on semi-quantitative and quantitative estimates of the breach probabilities of MDLOFs. For example, the ratio between the volume of dangerous ice of the parent glacier and lake volume was labeled the moraine lake outburst dangerous index by Lv et al. (1999); similarly, the danger levels of a moraine-dammed lake are calculated from the ratio between the volume of possibly falling matter and lake volume (Huggel et al., 2004). McKillop and Clague (2007b) proposed an approach to estimate the probabilities using logistic regression methods and remote-sensing data. Statistical approaches should be prudentially applied to calculate the breaching probabilities of MDLOFs in different areas (such as the Himalaya) because failed lakes and calculation parameters have regional features. Quantifying the breach probabilities of MDLOFs using remote-sensing data will undoubtedly be beneficial for the Himalaya region because of its size and inaccessibility. To date, only morainedammed lake outburst hazard events have been recorded in the Himalayas; therefore, in this paper, we analyze the potential hazard posed by moraine-dammed lakes, and establish a standardized, objective approach for making first-order estimates of the breach probabilities of moraine-dammed lakes in the Chinese Himalayas based on remote-sensing data.

\section{Study area}

The Himalayas have drawn wide attention in the context of the changing climate (ICIMOD, 2009; Bolch et al., 2012). In addition, the rapid melting of glaciers (glacier retreat) has resulted in the formation and expansion of glacial lakes, giving birth to PDMDLs (Richardson and Reynolds, 2000; Randhawa et al., 2005; Bajracharya et al., 2009; Sakai and Fujita, 2010; Salerno et al., 2012; Benn et al., 2012). In the Chinese Himalayas, which have a boundary of Gar Zangbu-Mapam Yumco-Yarlung Zangbu to the north and the China-IndiaBhutan national boundaries to the south (Fig. 1a), there is a transition of glaciers from maritime to continental type 
owing to the westward decrease in precipitation. Remotesensing surveys show that there were 1680 glaciers with a total area of $215.28 \mathrm{~km}^{2}$ in the 2000s in the Chinese Himalayas, and that as the glacial lake area has increased by $29 \%$ during the past $30 \mathrm{yr}$, the number and volume of PDMDLs have also increased (Che et al., 2004; Chen et al., 2007; Wang et al., 2012). MDLOFs are common natural hazards in the Chinese Himalayas, and notable events include 15 recorded MDLOF disasters since the middle of last century; sudden outburst floods or debris flows resulted in the loss of more than 600 lives ( $\mathrm{Lv}$ et al., 1999). The most devastating disaster was the failure of Sanswang, which killed more than 400 people. Another notorious disaster was the failure of Zhangzangbu in 1981, which killed more than 200 people and destroyed power stations, roads, bridges and farmland both in Nepal and China (Lv et al., 1999; Mool et al., 2001a).

\section{Database}

The data used in this paper included aerial-survey topographic maps, digital elevation models (DEMs), aerial photographs, ASTER (Advanced Spaceborne Thermal Emission and Reflection) images and meteorological data. There were 241 maps at a scale of $1: 50000,31$ at $1: 100000$, and six at $1: 25000$, which reflect information of glacial lakes during the period of approximately 1960-1990; the maps were available from the library of the Cold and Arid Regions Environmental and Engineering Research Institute. The DEM data were digital products derived from aerial-survey topographic maps, which were obtained from the Lanzhou Military Area Command of the People's Liberation Army. We examined the maps and DEMs to obtain geometric parameters (e.g. slope, width, length, and height) of moraine dams and parent glaciers. Aerial photographs were the original source data of topographic maps and were mainly used to distinguish the ice core from ice-free moraines guided by the interpretation criteria of McKillop and Clauge (2007b); they can be viewed at the library of the State Key Laboratory of Cryosphere Science, Cold and Arid Regions Environmental and Engineering Research Institute, Chinese Academy of Sciences.

There were 38 ASTER images covering the region of interest, and seven Landsat Thematic Mapper (TM) images were used to fill minor gaps between ASTER images. ASTER image data acquired in the 2000s were obtained from the USGS. The ASTER images of band $1(0.52-0.60 \mu \mathrm{m})$ and band $4(1.60-1.70 \mu \mathrm{m})$ were used to obtain the rate of change in the area of glacial lakes by comparing with the area derived from topographic maps, and they assist in interpreting the type of lake and distinguishing between an ice core and ice-free moraine dam.

Meteorological data included daily temperature and precipitation from nine meteorological stations in the study region and covered a period from the middle of last century to the end of 2006. The data were used to measure the factors of climatic forces.

To verify the reliability of the approach presented in this paper, two lakes - Longbasaba and Pida - located in Pumqu in the Chinese Himalayas at latitude $27^{\circ} 56.67^{\prime} \mathrm{N}$ and longitude $88^{\circ} 04.21^{\prime} \mathrm{E}$ (Fig. 1b, c and d) were surveyed in situ in the summers of 2006 and 2009. For each lake, we examined the lake volume of water and its change, moraine dam geometric parameters (slope, width, length, and height), the presence of dead ice inside the dam, and the status of the parent-glacier surface at the terminus including speed of motion, slope, frequency of cracking and icefall, and drainage system of the moraine dam.

\section{Development of an estimation model}

This section develops a method to estimate the breach probabilities of moraine-dammed lakes in the Himalayas. Our approach has two steps: we first select indicators to identify PDMDLs and then take a more objective approach to calculate the breach probability of each PDMDL.

\subsection{Candidate identifying indicators}

To first identify PDMDLs, we chose candidate-identifying indicators of PDMDLs according to the literature on moraine dam failures. Indicators are only included if they meet four criteria. First, indicators should be objectively measured and repeat measurements should be consistent. Second, indicators should have qualitative or semi-quantitative judgment criteria so as to determine grades of potential hazard. Third, the selected indicators should be generalized for sample MDLOFs in the Himalayas. Fourth, data of the selected indicators should be obtained through remote sensing and not fieldwork. According to these four criteria, the selected identifying indicators of PDMDLs in the Himalayas of China are presented in Table 1, and we interpret the indicators in the Discussion section.

\subsection{Event tree method}

Nineteen moraine-dam failure events on the Tibet Plateau have been field surveyed and documented in detail (Fig. 1a, Table 2). In this paper, the documented materials of the 19 failed lakes were used as basis data to establish a decisionmaking tree model for estimating the breach probabilities of PDMDLs. The model was developed as follows.

First, we determined the preconditions causing the failure of moraine-dammed lakes. The preconditions here refer to background forces closely related to the glacial lake outburst. Generally speaking, a moraine-dammed lake breach intrinsically results from the accumulation of water and heat. Therefore, the background of the climate can be regarded as the preconditions of the moraine-dam failure, with the abnormal climate changes facilitating MDLOF events (Lv et al., 1999; 
Table 1. Selected indicators of PDMDLs.

\begin{tabular}{ll}
\hline Indicator & Criterion \\
\hline morphological type & moraine-dammed lake \\
size of moraine-dammed lake & more than $1 \times 10^{5} \mathrm{~m}^{2}$ \\
change in moraine-dammed lake area & obviously enlarging \\
material characteristics of moraine dam & loose/formed since the Little Ice Age \\
distance between lake and parent glacier & less than $500 \mathrm{~m}$ \\
\hline
\end{tabular}

Table 2. Documented MDLOF events for moraine-dammed lakes on the Tibetan Plateau, their size and available data.

\begin{tabular}{|c|c|c|c|c|c|c|}
\hline No.* & Lake & $\begin{array}{l}\text { Lat. } \\
(\mathrm{N})\end{array}$ & $\begin{array}{l}\text { Long. } \\
\text { (E) }\end{array}$ & $\begin{array}{l}\text { Flood } \\
\text { date }\end{array}$ & $\begin{array}{l}\text { Volume/peak } \\
\text { flow } \\
\left(10^{6} \mathrm{~m}^{3} / \mathrm{m}^{3} \mathrm{~s}^{-1}\right)\end{array}$ & $\begin{array}{l}\text { Available data } \\
\text { or documents** }\end{array}$ \\
\hline 1 & Longdaco, China & $28^{\circ} 40^{\prime}$ & $85^{\circ} 25^{\prime}$ & 1964.8 .25 & $10.8 /-$ & DEM, topography map, aerial photo \\
\hline 2 & Zhangzangbu, China & $28^{\circ} 04^{\prime}$ & $86^{\circ} 04^{\prime}$ & 1981.7.11 & $19 / 1600$ & DEM, topography map, aerial photo \\
\hline 3 & Taraco, China & $28^{\circ} 18^{\prime}$ & $86^{\circ} 08^{\prime}$ & 1935.86. & $3 /-$ & DEM, topography map, aerial photo \\
\hline 4 & Ayaco, China & $28^{\circ} 21^{\prime}$ & $86^{\circ} 29^{\prime}$ & $\begin{array}{l}1968.8 .15 \\
1969.8 .17 \\
1970.8 .18\end{array}$ & $\begin{array}{l}-/- \\
-/- \\
90 /-\end{array}$ & DEM, topography map, aerial photo \\
\hline 5 & Jinco, China & $28^{\circ} 12^{\prime}$ & $87^{\circ} 39^{\prime}$ & 1982.8.27 & $12.8 /-$ & DEM, topography map, aerial photo \\
\hline 6 & Gelhaipco, China & $27^{\circ} 58^{\prime}$ & $87^{\circ} 49^{\prime}$ & 1964.9.21 & $23.4 / 4500$ & DEM, topography map, aerial photo \\
\hline 7 & Qunbixiamaco, China & $27^{\circ} 51^{\prime}$ & $88^{\circ} 55^{\prime}$ & 1940.7.10 & $12.4 / 3690$ & DEM, topography map, aerial photo \\
\hline 8 & Sangwangco, China & $28^{\circ} 14^{\prime}$ & $90^{\circ} 06^{\prime}$ & 1954.7.16 & $300 / \sim 10^{4}$ & DEM, topography map, aerial photo \\
\hline 9 & Zarico, China & $28^{\circ} 12^{\prime}$ & $90^{\circ} 23^{\prime}$ & 1981.6.24 & $-/-$ & DEM, topography map, aerial photo \\
\hline 10 & Degapuco, China & $28^{\circ} 26^{\prime}$ & $91^{\circ} 07^{\prime}$ & 2002.9.18 & $-/-$ & DEM, topography map, aerial photo, ASTER image \\
\hline 11 & Damenlahecho, China & $29^{\circ} 52^{\prime}$ & $93^{\circ} 02^{\prime}$ & 1964.9.26 & $2 / 2000$ & DEM, topography map, aerial photo \\
\hline 12 & Bogeco, China & $31^{\circ} 44^{\prime}$ & $94^{\circ} 43^{\prime}$ & 1972.7 .23 & & DEM, topography map, aerial photo \\
\hline 13 & Guanxieco, China & $29^{\circ} 28^{\prime}$ & $96^{\circ} 30^{\prime}$ & 1988.7.15 & & DEM, topography map, aerial photo \\
\hline 14 & Lugge Tsho, Bhutan & $28^{\circ} 05^{\prime}$ & $90^{\circ} 18^{\prime}$ & 1994.10.7 & $17.2 /-$ & Fujita et al. (2008), SPOT \\
\hline 15 & Nagma Pokhari, Nepal & $27^{\circ} 52^{\prime}$ & $87^{\circ} 52^{\prime}$ & 1980.6 .23 & $-1-$ & Bajracharya et al. (2007) \\
\hline 16 & Nare, Nepal & $27^{\circ} 50^{\prime}$ & $86^{\circ} 50^{\prime}$ & 1977.9 .3 & $-/-$ & Bajracharya et al. (2007) \\
\hline 17 & Tam Pokhari, Nepal & $27^{\circ} 44^{\prime}$ & $86^{\circ} 51^{\prime}$ & 1998.9 .3 & $17 /-$ & Bajracharya et al. (2007), TM image \\
\hline 18 & Dig Tsho, Nepal & $27^{\circ} 02^{\prime}$ & $86^{\circ} 35^{\prime}$ & 1985.8 .4 & $\begin{array}{l}6-10 / 1600- \\
2350\end{array}$ & Vuichard and Zimmerman. (1987) \\
\hline 19 & Chubung, Nepal & $27^{\circ} 53^{\prime}$ & $86^{\circ} 28^{\prime}$ & 1991.7.12 & $-/-$ & Mool et al. (2001a), TM image \\
\hline
\end{tabular}

* The number identifying the MDLOF lake in Fig. 1. ** For MDLOFs No. 1 to No. 13, we also referenced the documents of Liu and Sharma (1988), Xu and Feng (1989) and Lv et al. (1999), which summarized in situ surveys in China.

Cheng et al., 2009). To measure the climatic preconditions, we analyzed average temperatures for the last three summers (from June to September) and annual precipitation for the last three years before the occurrence of each historic MDLOF event. In addition, the wet-dry precipitation condition and warm-cold temperature condition were rated; the rating criteria are listed in Table 3. According to analysis of the climatic background of the documented MDLOF events on the Tibet Plateau, historic MDLOF preconditions were divided into four types: warm-wet, warm-arid, cold-wet and normal climate. Among the events, $40 \%$ of MDLOFs occurred after warm-wet conditions, $34 \%$ after warm-dry conditions, $13 \%$ after cold-wet conditions and $13 \%$ after conditions of normal climate.

Second, we constructed an event tree of moraine dam failure. Under certain climatic preconditions and during the accumulation of lake water and heat in a PDMDL basin, the physical status of the parent glacier, the lake water, and moraine dam may inevitably change. The lake may eventually fail via a trigger mechanism or a dominant trigger mechanism integrated with secondary trigger mechanisms. Therefore, an MDLOF event is essentially a cause-and-effect chain 
Table 3. Climatic preconditions causing moraine-dam failure and the discriminating criteria.

\begin{tabular}{|c|c|c|}
\hline Code & Climatic precondition $(i)$ & Criteria \\
\hline A & wet year & $\begin{array}{l}\text { annual precipitation } \geq \text { (average annual precipitation over } 40 \mathrm{yr}+10 \% \text { of average annual } \\
\text { precipitation over } 40 \mathrm{yr} \text { ) }\end{array}$ \\
\hline B & dry year & $\begin{array}{l}\text { annual precipitation } \leq \text { (average annual precipitation over } 40 \mathrm{yr}-10 \% \text { of average an- } \\
\text { nual precipitation over } 40 \mathrm{yr})\end{array}$ \\
\hline $\mathrm{C}$ & warm summer & $\begin{array}{l}\text { daily average temperature of summer (June-September) } \geq \text { (daily average temperature } \\
\text { of summer (June-September) over } 40 \mathrm{yrs}+0.1^{\circ} \mathrm{C} \text { ) }\end{array}$ \\
\hline $\mathrm{D}$ & cold summer & $\begin{array}{l}\text { daily average temperature of summer (June-September) } \leq \text { (daily average temperature } \\
\left.\text { of summer (June-September) over } 40 \mathrm{yr}-0.1^{\circ} \mathrm{C}\right)\end{array}$ \\
\hline $\mathrm{E}$ & normal year & $\begin{array}{l}\text { annual precipitation varied between } \mathrm{A} \text { and } \mathrm{B} \text {, daily average temperature of summer } \\
\text { (June-September) varied between } \mathrm{C} \text { and } \mathrm{D}\end{array}$ \\
\hline
\end{tabular}

process and can be described as a sequential event tree. In establishing an event tree method for a potentially dangerous glacial lake, all possible breach modes should be considered under all possible climatic preconditions. On the basis of the mechanism documented for 19 failed moraine dams (Liu and Sharma, 1988; Xu and Feng, 1989; Lv et al., 1999; Bajracharya et al., 2007; Mool et al., 2001a, b), under different climatic preconditions, we distinguished the precursory developments of MDLOFs and subdivided a sequential event tree of an MDLOF into 17 possible breach modes, with each mode having three or four components; we combined the preconditions and the mode and its chain components to construct a decision-making tree of moraine-dam failure (Table 4).

Third, we calculated the breaching probability of the potentially dangerous moraine-dammed lake using a decisionmaking tree for the failure of the moraine dam as follows.

(1) Under a certain climatic precondition, the occurrence probability for a chain component of a breach mode follows the conditional probability law, and can be expressed as

$P(i, j)=\prod_{k=1}^{s} P(i, j, k)$

where $P(i, j)$ is the probability of a moraine dam failing under the $i$-th climatic precondition for the $j$-th precursory developments; $i=1,2, \ldots, m$ is the climatic precondition; $j=$ $1,2, \ldots, n$ is the precursory developments; and $k=1,2, \ldots, s$ is the component of precursory developments.

(2) All breach modes are not mutually exclusive under a certain climatic precondition (i.e. the failure of the morainedammed lake can be triggered by several breaching modes simultaneously). Therefore, the occurrence probability for all possible modes under a certain precondition should be calculated using De Morgan's law. In the case of precondition $i$, the upper bound conditional probability estimated from De Morgan's law is the occurrence probability of all possible modes, which is equal to one minus the product of the complements:

$P\left(A_{1 i}+A_{2 i}+\cdots+A_{n i}\right)=1-\prod_{j=1}^{n}[1-P(i, j)]$

where $P\left(A_{1 i}, A_{2 i}, \ldots, A_{n i}\right)$ is the estimated upper bound conditional probability of failure under precondition $i ; A_{1 i}$, $A_{2 i}, \ldots, A_{n i}$ are several individual breach modes under precondition $i$; and $P_{1 i}$ to $P_{n i}$ are the estimates of the occurrence probabilities of several individual breach modes under precondition $i$.

(3) Different preconditions are mutually exclusive in that the moraine-dam failure is usually not repeatable (e.g. among 19 documented MDLOFs in the Himalayas, only Ayaco repeatedly breached, in 1968, 1969 and 1970). Thus, it is supposed that the dam of a PDMDL only fails under a certain climatic precondition and consequently follows the addition theorem of probability. That is, the ultimate dam-failure probability of a PDMDL is equal to the sum of probabilities calculated using Eq. (2) under different preconditions:

$P=\sum_{i=1}^{m} P\left(A_{1 i}+A_{2 i}+\ldots+A_{n i}\right)+E$,

where $E$ is a constant giving the occurrence probability for non-climatic modes, such as a dam failing owing to an earthquake or human engineering.

\subsection{Quantifying the probabilities of components in breach modes}

The occurrence probabilities of some components in breaching mode are generally estimated using expert judgment and guidelines for conversion between the qualitative description of components and quantitative magnitude probability (Huggel et al., 2004; McKillop et al., 2007; Mergili and Schneider, 2011), and the conversion guidelines have been described in detail for the probability of earth-dam failure (Peng, 2003). A weighing scheme of ordering the selected 
Table 4. Breaching mode and its chain components for a moraine-dammed lake under different climatic preconditions.

\begin{tabular}{|c|c|c|c|c|c|c|c|c|}
\hline \multicolumn{4}{|c|}{ Climatic preconditions $(i)$} & \multicolumn{5}{|c|}{ Precursory developments $(j)$} \\
\hline Warm-wet & Warm-dry & Cold-wet & Normal & & & Key component $(k)$ & & \\
\hline \multirow[t]{2}{*}{$\mathrm{X}$} & $\mathrm{X}$ & $\mathrm{X}$ & $\mathrm{X}$ & & ice-flow speeding up & avalanche & wave-induced incision & dam breach \\
\hline & & $\mathrm{X}$ & & $\begin{array}{l}\text { positive mass } \\
\text { balance }\end{array}$ & ice-flow speeding up & glacier moving faster & wave-induced incision & dam breach \\
\hline $\mathrm{X}$ & $\mathrm{X}$ & & $\mathrm{X}$ & & ice bed thawing & glacier moving faster & wave-induced incision & dam breach \\
\hline $\mathrm{X}$ & $\mathrm{X}$ & & $\mathrm{X}$ & & glacier strongly melting & overflow incision & & dam breach \\
\hline $\mathrm{X}$ & & $\mathrm{X}$ & $\mathrm{X}$ & & heavy rain/snow & overflow incision & & dam breach \\
\hline $\mathrm{X}$ & $\mathrm{X}$ & & $\mathrm{X}$ & $\begin{array}{l}\text { heat accumula- } \\
\text { tion in dam }\end{array}$ & ice thawing in dam & seepage enlarging & & dam breach \\
\hline
\end{tabular}

variables after the estimation of hazard potential from highest to lowest has been constructed according to the literature and past MDLOF events (Bolch et al., 2011). In this paper, we establish conversion guidelines so as to quantify the probabilities of components of a breach mode for moraine-dam failure employing the historic performance method combined with expert knowledge and experience. The historic performance method considers the probability of historic MDLOF events to determine the possibility of MDLOF events occurring in the future. We abstract the relationships between breach mode components of the documented MDLOF events on the Tibetan Plateau and generalize the guidelines for conversion between the occurrence probability magnitudes of components and physical characteristics of the parent glacier, dam and lake basin (Table 5).

Theoretically, the occurrence probability of each component for a breach mode under a climatic precondition should be evaluated, and eventually, a description of the probability of the whole event tree of the moraine-dam failure is obtained. However, given the limited knowledge available and required simplifications, only the key component (e.g. an avalanche, a glacier moving more quickly, seepage enlargement or overflow incision) in a breach mode is evaluated with different probability magnitudes according to physical characteristics of the parent glacier, dam and lake basin, as presented in Table 5. This is a feasible approach because the key components of precursory developments presented in Table 4 indicate the mechanism of the lake outburst, and they were the key factors resulting in dam breach.

Although their precursory developments are forced by climatic factors, the non-climatic components, such as earthquakes and engineering, fall outside the application domain of our event tree method. Although the components are not found to trigger MDLOFs at present on the Tibetan Plateau, we cannot rule out their future effects. We arbitrarily quantify the non-climatic components with an occurrence probability magnitude of 0.01 (constant $E$ in Eq. 3) guided by the evaluation method for reservoir failure (Peng, 2003). Each indicator of the physical setting is scored independently; i.e. a single indicator with a high occurrence probability magnitude may be sufficient for the overall probability of the key component being high, irrespective of the ratings of other indicators of the key component. Further explanations of the guidelines in Table 5 are as follows.

(1) The volume of dangerous glacier (VDG) refers to the glacier volume from the location of abrupt change in the slope to the glacier terminus or the volume of terminal glacier where ice cracks are well developed, and the index of the VDG is the ratio of the VDG to the volume of lake water. The VDG is the area of dangerous glacier multiplied by the thickness of dangerous glacier. The area of dangerous glacier was measured from the topographical map and the thickness of the dangerous glacier was largely calculated using (Paterson, 1994)

$h=\tau / k \rho g \sin \alpha$,

where $\tau$ is the shear stress across the bottom of the dangerous glacier, largely ranging from $100 \mathrm{kPa}$ for small mountain glaciers to $150 \mathrm{kPa}$ for large mountain glaciers (Haeberli and Hoelzele, 1995); $\rho=900 \mathrm{~kg} \mathrm{~m}^{-3}$ is the density; $g=10 \mathrm{~m} \mathrm{~s}^{-1}$ is acceleration due to gravity; $\alpha$ is the average surface slope of the VDG; and $k$ is a factor in the range of 0.5 to 0.9 for a valley glacier (Paterson, 1994). Several statistical formulae are available for calculating the lake volume $(V)$ from the lake area $(A)$ (Huggel et al., 2002; McKillop et al., 2007a; Yao et al., 2012). To calculate the lake volume, we summarized in situ measurements for 20 moraine-dammed lakes in the Himalayas from the literature, which yielded

$V=0.0354 A^{1.3724}$ where $r^{2}=0.919$.

The regression of volume against area has a very high coefficient of determination $\left(r^{2}=0.919\right)$, reflecting the dependency of volume on area. However, volume is generally calculated from area and depth measurements, and the use of lake area in both variables of Eq. (5) suppresses the relatively large scatter in the relation between the originally measured lake area and water depth, and thus suppresses important information about the uncertainties involved in the applied correlation. It is more reasonable to plot the mean water depth against lake area. The lake depth-area regression for the 20 moraine-dammed lakes in the Himalayas is

$D=0.087 A^{0.434}$ where $r^{2}=0.503$. 
Table 5. Guidelines for quantifying the occurrence probabilities of key components of precursory developments on the basis of physical characteristics of the parent glacier, dam and lake basin of documented MDLOF events on the Tibetan Plateau.

\begin{tabular}{|c|c|c|c|c|c|}
\hline \multirow{2}{*}{ Key component $(k)$} & \multirow{2}{*}{ Indicator of physical setting } & \multicolumn{4}{|c|}{ Occurrence probability magnitude } \\
\hline & & $>0.7$ & $0.7-0.3$ & $0.3-0.1$ & $<0.1$ \\
\hline \multirow{3}{*}{ avalanche } & index of $\mathrm{VDG}^{\mathrm{a}}$ & $>0.3$ & $0.1-0.3$ & $0.01-0.1$ & $<0.01$ \\
\hline & ice cracking of VDG & $\begin{array}{l}\text { ice cracks } \\
\text { developed and icefall } \\
\text { occurred }\end{array}$ & $\begin{array}{l}\text { ice cracks } \\
\text { developed }\end{array}$ & ice cracks observed & no ice cracks observed \\
\hline & slope of VDG $\left(^{\circ}\right)$ & $>20$ & $8-20$ & $3-8$ & $<3$ \\
\hline \multirow{3}{*}{ glacier motion } & distance from VDG to lake (m) & $\begin{array}{l}\text { VDG extended into the } \\
\text { lake }\end{array}$ & 0 & $0-500$ & $>500$ \\
\hline & distance of lake to glacier (m) & $\begin{array}{l}\text { zero; glacier moving } \\
\text { more quickly }\end{array}$ & 0 & $0-500$ & $>500$ \\
\hline & slope of glacier tongue $\left({ }^{\circ}\right)$ & $>20$ & $8-20$ & $3-8$ & $<3$ \\
\hline \multirow{2}{*}{ seepage enlarging } & DWH ratio $^{\mathrm{b}}$ & $<1$ & $1-2$ & $2-10$ & $>10$ \\
\hline & dead ice in dam & $\begin{array}{l}\text { undulated dam surface } \\
\text { indicating dead ice } \\
\text { melting }\end{array}$ & dead ice exists & $\begin{array}{l}\text { dead ice possibly } \\
\text { exists }\end{array}$ & no dead ice detected \\
\hline \multirow{2}{*}{ overflow incision } & DWH ratio ${ }^{b}$ & $<1$ & $1-2$ & $2-10$ & $>10$ \\
\hline & Ratio of freeboard to dam height & $\begin{array}{l}\text { zero, overflow } \\
\text { emergence and loose } \\
\text { moraine being eroded }\end{array}$ & near zero & relatively small & relatively large \\
\hline
\end{tabular}

a VDG is the volume of dangerous glacier, which refers to the glacier volume from the location of abrupt change in the slope to the glacier terminal, or the volume of the terminal glacier where ice cracks are well developed; the index of the VDG is the ratio of the VDG to the volume of lake water. ${ }^{\mathrm{b}}$ The DWH ratio is the ratio of the dam width to height.

For the moraine-dammed lakes in the Himalayas, there is a statistically significant power trend $(\alpha<0.05)$ between the lake area and depth. To calculate the depth of each PDMDL, Eq. (5) can be rewritten as

$D=0.0354 A^{0.3724}$.

The depth of each PDMDL can be calculated using either Eq. (6) or Eq. (7), and the relative value of difference between calculated depths is

[|Depth resulted from Eq. (7) - Depth resulted from Eq. (8)|/

Depth resulted from Eq. (7)] $\times 100 \%$.

The relative differences between depths calculated with Eq. (6) and those calculated with Eq. (7) among all PDMDLs ranged from $0.42 \%$ to $14.3 \%$ and had an average value of $8.2 \%$. These results convey the uncertainty due to the high variability of lake geometry in nature.

Data are available for 11 of the 19 MDLOFs to calculate their VDG index before failure. Results show that the VDG indexes varied $0.11-0.52$, with $80 \%$ of values exceeding 0.3 . On the other hand, Huggel et al. (2004) believed that if the ratio of the volume of material falling into the lake to water volume is $1-0.1$, then the moraine-dammed lake will breach completely; if the ratio of the volume of material falling into the lake to water volume is $0.1-0.01$, then the breach probability is high. Therefore, we take $0.3,0.1$ and 0.01 as the thresholds of the VDG index to quantify the occurrence probabilities.
(2) The slope thresholds of the glacier tongue or VDG of the parent glacier are set at $20^{\circ}, 8^{\circ}$ and $3^{\circ}$ since the slope of the parent glacier tongue of documented GLOF lakes varies $3^{\circ}-20^{\circ}$ but more than half exceed $8^{\circ}$ on the Tibetan Plateau (Lv et al., 1999).

(3) Among the 19 documented MDLOF events on the Tibetan Plateau, all glacier terminuses were closer than $500 \mathrm{~m}$ to their respective lakes, with 14 extending into their lakes. If the glacier terminus extends into the lake, the terminus will melt along the surface water by thermal undercutting, which increases the probability of an MDLOF event ( $\mathrm{Lv}$ et al., 1999; Cui et al., 2003). Therefore, the distance from the lake to the glacier terminal was categorized as extension into the lake, $0 \mathrm{~m}, 0-500 \mathrm{~m}$ or $>500 \mathrm{~m}$.

(4) Moraine-dam failure usually involves aspects of slope stability, piping (progressive groundwater flow) and/or retrogressive erosion. Generally, the smaller the dam width to height $(\mathrm{DWH})$ ratio is, the more likely the dam is to breach when only the DWH ratio is considered (Huggel et al., 2002; Clague and Evans, 2000). Huggel et al. (2004) believed that moraine dams with DWH ratio less than 1 are susceptible to breach in the Swiss Alps. However, moraine dams in the Himalayas are usually larger than those in the Alps. Calculations show that the DWH ratio for past-documented MDLOFs varied from 0.6 to 1.7 . Additionally, we arbitrarily consider that a lake with a DWH ratio more than 10 has a low probability to breach. 
(5) Moraine dams of PDMDLs in the study area comprise loose moraine. The presence of dead ice in a moraine dam is a potentially dangerous trigger of breaching (Yesenov and Degovets, 1979; Reynolds et al., 1998; Richardson and Reynolds, 2000; Kattelmann, 2003), and when the melting of the dead ice accelerates, greater seepage becomes more likely.

(6) Ratio of freeboard to dam height. The ratio of freeboard to dam height (here we chose the lowest part of the dam to measure the dam height and freeboard) directly indicates the possibility of overflow incision, and the lower the ratio of freeboard to dam height is, the more likely the dam is exposed to overflow incision (Huggel et al., 2004; Bolch et al., 2008). Although no guidelines were found in the literature to quantify the occurrence probability magnitude of overflow incision according to the ratio of freeboard to dam height, there should undoubtedly be high probability when the ratio of freeboard to dam height approaches zero, especially when overflow emerges and the loose moraine of the dam is being eroded.

\section{Model results}

According to the selected indicators in Table 1, there are 142 PDMDLs among the 1680 present-day lakes in the Chinese Himalaya; the PDMDLs have a total area of $68.13 \mathrm{~km}^{2}$ and an average altitude of $5220 \mathrm{~m}$. The outburst probability of the 142 lakes ranged from 0.037 to 0.345 as determined using the above event tree method. Guided by a prioritization rule for the outburst probability of moraine-dammed lakes from very high to very low (McKillop and Clague, 2007b), we classify outburst probabilities of the 142 lakes as very low (four lakes, $<0.06$ ), low (24 lakes, 0.06-0.12), medium (24 lakes, 0.12-0.18), high (47 lakes, $0.18-0.24$ ), and very high (43 lakes, >0.24), as shown in Figs. 1a and 4. Two PDMDLs in the Pumqu basin of the Chinese Himalayas, which have outburst probability categories of "very high" (A, $\left.87^{\circ} 38^{\prime} \mathrm{E}, 28^{\circ} 06^{\prime} \mathrm{N}\right)$ and "medium" (B, $\left.87^{\circ} 37^{\prime} \mathrm{E}, 28^{\circ} 07^{\prime} \mathrm{N}\right)$, and a non-PDMDL $\left(\mathrm{C}, 87^{\circ} 39^{\prime} \mathrm{E}, 28^{\circ} 07^{\prime} \mathrm{N}\right)$ are seen in the aerial photograph in Fig. 2.

\section{Discussions}

\subsection{Potential sources of error}

The reliability of the breach probability depends, to a large degree, on the quality of the data on which it is based. First, the source data of the model parameters are for different time periods, which undoubtedly introduces errors. The geometric parameters of the moraine dam were originally obtained from aerial photographs taken in the 1970s and 1980s; however, we take the data as representative of the 2000s when calculating the probability of glacial lake outburst. It is feasible that the geometric parameters of a dam have not changed greatly

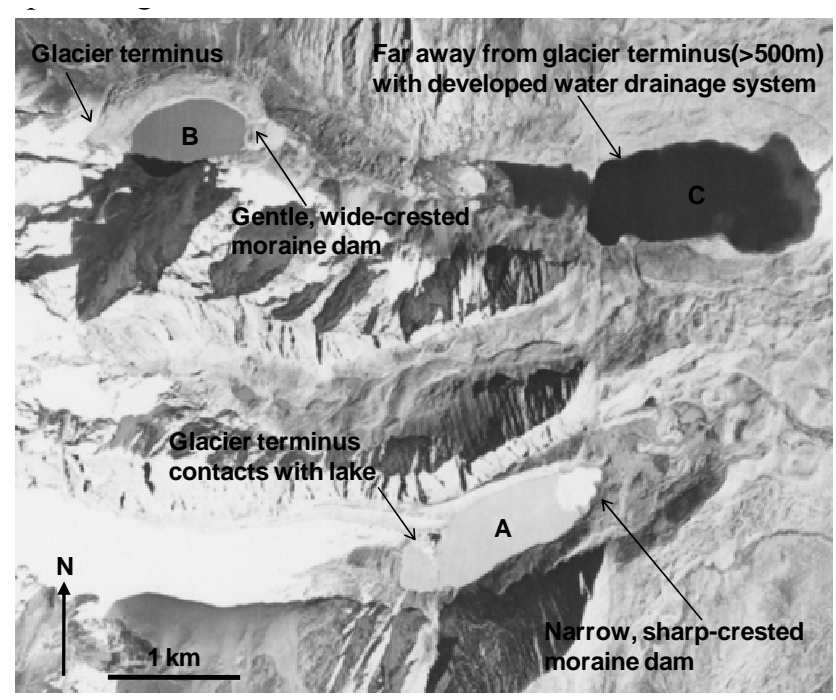

Fig. 2. Two lakes having outburst probabilities of "very high" (A, $\left.87^{\circ} 38^{\prime} \mathrm{E}, 28^{\circ} 06^{\prime} \mathrm{N}\right)$ and "medium" (B, $\left.87^{\circ} 37^{\prime} \mathrm{E}, 28^{\circ} 07^{\prime} \mathrm{N}\right)$ and a non-PDMDL $\left(\mathrm{C}, 87^{\circ} 39^{\prime} \mathrm{E}, 28^{\circ} 07^{\prime} \mathrm{N}\right)$ in the Pumqu basin of the Himalayas are seen in an aerial photograph. The aerial photograph was reproduced with permission from the Cold and Arid Regions Environmental and Engineering Research Institute.

during the past $30 \mathrm{yr}$. We obtain the slope of the tongue of a parent glacier from a DEM as representative of the slope in the 2000s, and the slope in the 1970s may be inconsistent with that in the 2000s because of different melting rates during the past $30 \mathrm{yr}$. However, it is acceptable to consider that local inconsistencies of melting have a limited effect on the slope of the whole glacier tongue. Second, the ASTER images cover different seasons in a 5-yr period (2004-2008), and thus, the geometric parameters of parent glaciers include both seasonal and annual inconsistencies. We cannot quantitatively evaluate the error due to this temporal variation. However, the probabilities estimated by the model are eventually grouped into probability intervals, which reduce the effect of temporal inconsistencies. In addition, as an indicator of the change in lake area to identify PDGLs (potentially dangerous glacial lakes), we simply consider whether the lake area is expanding or not, with no consideration of the magnitude of the expansion, which reduces the effects of temporal errors.

Some errors in the remote-sensing data may result in misinterpretations; for example, the physical attributes of the moraine dam and the outline of the glacial lake may be misinterpreted owing to snow cover, cloud cover, shadows, and distortion due to high-relief terrain. Photogrammetric measurements may be inaccurate owing to limitations imposed by aerial photography and the ASTER image scale, object clarity, and the skill of the interpreter. In this study, percentage errors in distance and slope measurements were evaluated by comparing aerial photographs and ground 
Table 6. Comparison of aerial photogrammetric measurements with field-based measurements.

\begin{tabular}{|c|c|c|c|c|c|c|c|}
\hline \multirow[t]{2}{*}{ Lake } & \multirow{2}{*}{$\begin{array}{l}\text { Lat. } \\
(\mathrm{N})\end{array}$} & \multirow{2}{*}{$\begin{array}{l}\text { Long. } \\
\text { (E) }\end{array}$} & \multirow{2}{*}{$\begin{array}{l}\text { Terrain } \\
\text { feature }\end{array}$} & \multicolumn{3}{|c|}{ Measurement } & \multirow{2}{*}{$\begin{array}{l}\text { Source of field } \\
\text { measurement data }\end{array}$} \\
\hline & & & & Field & Photogrammetric & $\begin{array}{r}\text { Error } \\
(\%)\end{array}$ & \\
\hline Zonggyaco & $28^{\circ} 07^{\prime}$ & $87^{\circ} 39^{\prime}$ & crest width of moraine dam (m) & 40 & 44 & 10 & Liu and Sharma (1988) \\
\hline Riwopuco & $28^{\circ} 03^{\prime}$ & $87^{\circ} 38^{\prime}$ & crest width of moraine dam (m) & 25 & 27 & 8 & Liu and Sharma (1988) \\
\hline Qangzonkco & $27^{\circ} 56^{\prime}$ & $87^{\circ} 46^{\prime}$ & crest width of moraine dam (m) & 30 & 26 & 13 & Liu and Sharma (1988) \\
\hline Longbasaba & $27^{\circ} 57^{\prime}$ & $88^{\circ} 04^{\prime}$ & crest width of moraine dam (m) & 163 & 150 & 8 & Wang et al. (2008) \\
\hline Bugaco & $28^{\circ} 14^{\prime}$ & $89^{\circ} 53^{\prime}$ & moraine dam height $(\mathrm{m})$ & 100 & 85 & 20 & Chen et al. (1996) \\
\hline Abmachimaico & $28^{\circ} 06^{\prime}$ & $87^{\circ} 38^{\prime}$ & moraine dam height (m) & 118 & 100 & 15 & Liu and Sharma (1988) \\
\hline Paquco & $28^{\circ} 18^{\prime}$ & $86^{\circ} 09^{\prime}$ & moraine dam height (m) & 80 & 65 & 19 & Liu and Sharma (1988) \\
\hline Riwopuco & $28^{\circ} 03^{\prime}$ & $87^{\circ} 38^{\prime}$ & moraine dam height (m) & 20 & 30 & 50 & Liu and Sharma (1988) \\
\hline Qangzonkco & $27^{\circ} 56^{\prime}$ & $87^{\circ} 46^{\prime}$ & moraine dam height (m) & 80 & 75 & 5 & Liu and Sharma (1988) \\
\hline Lake No.14 & $28^{\circ} 19^{\prime}$ & $85^{\circ} 50^{\prime}$ & moraine dam height $(\mathrm{m})$ & 80 & 90 & 13 & Liu and Sharma (1988) \\
\hline Zonggyaco & $28^{\circ} 27^{\prime}$ & $87^{\circ} 39^{\prime}$ & moraine dam height (m) & 40 & 48 & 20 & Liu and Sharma (1988) \\
\hline Longbasaba & $27^{\circ} 57^{\prime}$ & $88^{\circ} 04^{\prime}$ & moraine dam height $(\mathrm{m})$ & 100 & 96 & 4 & Wang et al. (2008) \\
\hline Paquco & $28^{\circ} 18^{\prime}$ & $86^{\circ} 09^{\prime}$ & dam slope outside $\left({ }^{\circ}\right)$ & 13 & 20 & 54 & Liu and Sharma (1988) \\
\hline Zonggyaco & $28^{\circ} 07^{\prime}$ & $87^{\circ} 39^{\prime}$ & dam slope outside $\left(^{\circ}\right)$ & 10 & 8 & 20 & Liu and Sharma (1988) \\
\hline Abmachimaico & $28^{\circ} 06^{\prime}$ & $87^{\circ} 38^{\prime}$ & dam slope outside $\left(^{\circ}\right)$ & 17 & 18 & 6 & Liu et al. (1988) \\
\hline Lake No.14 & $28^{\circ} 19^{\prime}$ & $85^{\circ} 50^{\prime}$ & dam slope outside $\left(^{\circ}\right)$ & 14 & 15 & 7 & Liu and Sharma (1988) \\
\hline Bugaco & $28^{\circ} 14^{\prime}$ & $89^{\circ} 53^{\prime}$ & dam slope outside $\left(^{\circ}\right)$ & 5 & 7 & 40 & Chen et al. (1996) \\
\hline Guangxieco & $29^{\circ} 25^{\prime}$ & $96^{\circ} 30^{\prime}$ & slope of parent glacier tongue $\left(^{\circ}\right)$ & 4 & 5 & 25 & Li and You (1992) \\
\hline Longbasaba & $27^{\circ} 57^{\prime}$ & $88^{\circ} 04^{\prime}$ & slope of parent glacier tongue $\left(^{\circ}\right)$ & 11 & 10 & 9 & Wang et al. (2008) \\
\hline Shenmoco & $28^{\circ} 16^{\prime}$ & $90^{\circ} 04^{\prime}$ & slope of parent glacier tongue $\left(^{\circ}\right)$ & 4 & 5 & 25 & Chen et al. (1996) \\
\hline Sheneco & $28^{\circ} 14^{\prime}$ & $90^{\circ} 06^{\prime}$ & slope of parent glacier tongue $\left(^{\circ}\right)$ & 30 & 28 & 7 & Chen et al. (1996) \\
\hline
\end{tabular}

error $=[$ photogrammetric measurement - field measurement $\mid /$ field measurement $] \times 100 \%$.

measurements. The absolute values of the distance measurement error vary from 2 to $20 \mathrm{~m}$ and the absolute values of the slope measurement error vary from $1^{\circ}$ to $7^{\circ}$. The percentage errors in distance measurements were generally less than $20 \%$, and the percentage errors in slope measurements were generally less than $25 \%$; the larger percentage errors (e.g. $54 \%$ and $50 \%$ ) were for smaller measurement values (Table 6).

\subsection{Selected indicator of a potentially dangerous glacial lake}

Indicators were selected to preliminarily identify the PDGLs before calculating breach probabilities. No non-morainedammed lake outburst hazard events have been recorded in the Himalayas. Thus, this article only analyzes the potential hazard posed by moraine-dammed lakes, although we cannot exclude the chance of future breaching events involving other types of lake.

Generally speaking, only a moraine-dammed lake larger than a certain size can possibly induce damage. The minimum magnitude of $10^{5} \mathrm{~m}^{2}$ for the lake area was taken as the threshold from the analysis of GLOF events in China (Lv et al., 1999; Cui et al., 2003). Some researchers have concluded that a glacial lake larger than $0.2 \mathrm{~km}^{2}$ may be a potential danger (Mool et al., 2001; Che et al., 2004). It can be said that the threshold for identifying potentially hazardous lakes is dynamic and should be adjusted according to socioeconomic development and the expansion of human activity to mountain areas. In this paper, we take the smallest magnitude $\left(10^{5} \mathrm{~m}^{2}\right)$ of historic GLOF events in the Himalayas as identification criteria and arbitrarily exclude lakes smaller than the threshold.

Old moraine-dammed lakes (formed before the Little Ice Age) are usually stable owing to the dams being consolidated or metamorphic. Therefore, we only consider lakes dammed by loose moraine and exclude lakes that formed before the Little Ice Age when identifying the PDGLs. Additionally, the dynamics of the parent glacier are directly associated with GLOF occurrence, and the distance between the lake and parent glacier is the most direct measure of the degree of their linkage. A horizontal distance threshold of $500 \mathrm{~m}$ is chosen in this paper since the horizontal distances between the lake and parent glacier for all recorded GLOF events in China were less than $500 \mathrm{~m}$ (Lv et al., 1999).

\subsection{Criteria of the occurrence probability magnitude}

At present, there are experiences or guidelines for conversion from qualitative descriptions to quantitative probability values in the case of MDLOF events (Huggel et al., 2004; McKillop et al., 2007; Mergili et al., 2011). On the basis 
of re-analysis of historic MDLOF events and guided by the methodology of prioritizing probability intervals of earthdammed lakes (Peng, 2003), we obtained quantitative criteria to quantify the occurrence probabilities of key components of breach modes (Table 5). Four probability intervals were set for each key component from the highest $(>0.7)$ to lowest $(<0.1)$ on the basis of photogrammetric measurements. However, it is difficult to apply some conversion guidelines to remote-sensing data, and there are uncertainties when making judgments using remote-sensing data. To make the judgments as objective as possible, we take the average of quantitative judgments made by three experts in assigning the probability of the key component.

\subsection{Prioritizing the breach probability intervals}

Using probability ranges or intervals instead of discrete values ensures that estimates do not convey more precision than is warranted. Numerous researchers arbitrarily categorized probabilities, particularly for display purposes (e.g. Dai and Lee, 2003; McKillop and Clague, 2007b). A curve showing the cumulative percentage of drained lakes versus probability provides a more objective basis for defining probability thresholds (Fig. 3), and the probability thresholds of $0.24,0.18,0.12$ and 0.06 were set to prioritize the morainedammed breaching probabilities as very high, high, medium, low and very low, respectively, in British Columbia (McKillop and Clague, 2007b). Model results indicate that the breach probabilities of the 142 PDGLs in the Chinese Himalayas ranged $0.037-0.345$, and it seems that the thresholds of $0.24,0.18,0.12$ and 0.06 can reasonably categorize the hazards from very high to very low. Two lakes that have very high and high breaching probabilities, Longbasaba and Pida (Fig. 1c and d), were investigated in the field in 2006 and 2009, and the in situ evaluation indicated the two lakes remained at a high risk of failure (Wang et al., 2008). On the other hand, there were six examples of lakes posing a high risk before breach and another seven lakes posing a low or medium risk after breach (see Sect. 6.5 and Fig. 4). Thus, probability thresholds of $0.24,0.18,0.12$ and 0.06 seem appropriate and were arbitrarily used to prioritize the probability rates in this paper.

\subsection{Reliability of the model results}

Generally speaking, as a potentially dangerous lake is about to breach, the accumulation of water of the lake basin gradually approaches maximum levels, and the hazard parameters should usually indicate the most dangerous status; thus, the breach probability should be theoretically "high". On the other hand, after a moraine-dammed lake has breached, the probability of another outburst should generally be low or even zero owing to (1) the large amount of water released instantaneously and (2) the melting water being unable to accumulate again in the lake basin because of the devastation

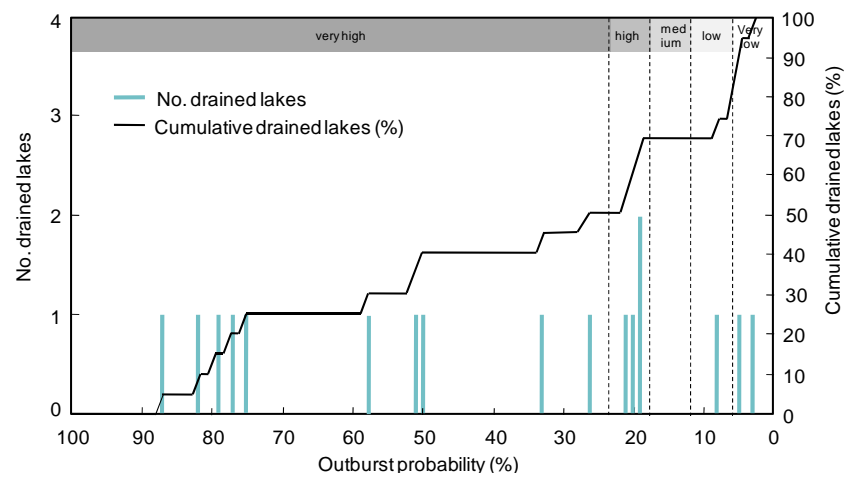

Fig. 3. Distribution of outburst probability estimates for drained lakes in southwestern British Columbia. The black curve is the cumulative percentage of drained lakes based on outburst probability estimates. Breaks in the slope of this curve, for example at $6 \%$, provide an objective basis for defining probability categories (top of graph) (McKillop et al., 2007b).

of the dam. Therefore, we can roughly validate the reliability of our model results by evaluating the breach probability of historic failed moraine-dammed lakes before or after outburst.

Fifteen moraine-dammed lakes in the Chinese Himalayas were selected as examples (Table 7, Fig. 4). According to the time at which calculation parameters were photogrammetrically measured, Bogeco, Zarico, Zhangzangbuco, Jinco, Guangxieco and Degapuco are representative of lakes before outburst, and their calculated probabilities of outburst fall in the range of $0.195-0.301$ and belong to the very high or high risk classes. Qunbixiamaco, Sangwangco, Damenlahecho, Longdaco, Taraco, Ayaco and Gelhaipco are representative of lakes after dam failure and have outburst probabilities in the range of 0.049-0.139; Sangwangco (0.139) and Taraco (0.129) belong to the medium risk class and the other five to the low or very low risk classes. Additionally, two lakes with very high and high calculated risk, Longbasaba and Pida, which were characterized by rates of area increase of 0.0277 and $0.0152 \mathrm{~km}^{2} \mathrm{a}^{-1}$ in $1978-2009$, respectively (Fig. 1b), were confirmed to have a high risk of failure in a field investigation (Wang et al., 2008). Consequently, the model for estimating the probability of morainedammed lake outburst in this paper is feasible and its results are reliable on the whole.

\subsection{Methodology}

An MDLOF usually results from a chain of processes involving the interaction of climatic variation, glacier dynamics, permafrost activity, lake change, dam response and down-valley characteristics (Huggel et al., 2004; McKillop et al., 2007a). Haeberili et al. (2010) provided a brief overview of existing knowledge of glacial lakes in highmountain environments, focusing on hazard assessment, 
Table 7. Probabilities for example moraine-dammed lakes showing the reliability of the event-tree model.

\begin{tabular}{llrlcl}
\hline No.* & Lake & $\begin{array}{r}\text { Flood } \\
\text { date }\end{array}$ & $\begin{array}{l}\text { Date of } \\
\text { parameter capture }\end{array}$ & $\begin{array}{l}\text { Occurrence } \\
\text { probability }\end{array}$ & $\begin{array}{l}\text { Prioritizing level } \\
\text { and remarks }\end{array}$ \\
\hline 1 & Longdaco & 1964.8 .25 & 1974.10 & 0.120 & after breach, medium \\
2 & Zhangzangbu & 1981.7 .11 & 1974.11 & 0.297 & before breach, very high \\
3 & Taraco & 1935.8 .6 & 1974.10 & 0.129 & after breach, medium \\
4 & Ayaco & 1968.8 .15 & 1980.11 & 0.103 & after breach, low \\
5 & Jinco & 1982.8 .27 & 1974.10 & 0.288 & before breach, very high \\
6 & Gelhaipco & 1964.9 .21 & 1978.7 & 0.049 & after breach, very low \\
7 & Qunbixiamaco & 1940.7 .10 & 1980.11 & 0.104 & after breach, low \\
8 & Sangwangco & 1954.7 .16 & 1980.11 & 0.139 & after breach, medium \\
9 & Zarico & 1981.6 .24 & 1980.11 & 0.264 & before breach, very high \\
10 & Degapuco & 2002.9 .18 & 1980.11 & 0.195 & before breach, high \\
11 & Damenlahecho & 1964.9 .26 & 1970.11 & 0.066 & after breach, low \\
12 & Bogeco & 1972.7 .23 & 1970.11 & 0.301 & before breach, very high \\
13 & Guanxieco & 1988.7 .15 & 1980.11 & 0.231 & before breach, high \\
& Longbasaba & - & 1978.7 & 0.296 & field survey verified, very high \\
& Pida & - & 1978.7 & 0.209 & field survey verified, high \\
\hline
\end{tabular}

* The number identifying the MDLOF lake in Fig. 1.

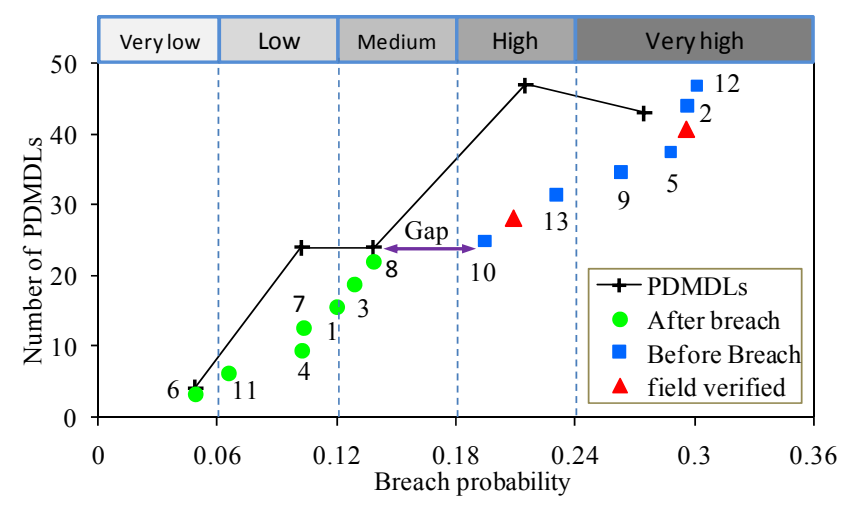

Fig. 4. Distribution of breach probability for PDMDLs and 15 example moraine-dammed lakes (numbers are the identifying numbers of the MDLOF lakes in Fig. 1a). The scale with intervals of 0.06 defines the probability rates (top of graph). The evident gap marked by the arrows between after-breach (very low to medium breach probability) and before-breach (high to very high breach probability) lakes shows the reliability of the event-tree model.

physical processes, and challenges facing future basic and applied research. Therefore, evaluating the hazards of the MDLOF is a systematic process that involves not only physical aspects (e.g. causes, outburst probability, magnitude, and trajectory), but also social factors (e.g. population density, response, preparedness, and prevention) (Carey, 2005; Hegglin and Huggel, 2008). In this article, we presented a first-order method to identify PDMDLs and estimate the outburst probability of moraine-dammed lakes from remote-sensing data.

There have been at least three achievements in identifying PDMDLs from remote-sensing data. It has been argued that the existence of (1) a gradual surface slope and displacement of the glacier tongue, (2) a relatively thin debris layer that lowers the glacier surface, and (3) a particularly deep part of the glacier bed favor the formation and development of PDMDLs (Reynolds, 2000; Quincey et al., 2007; Suzuki et al., 2007; Röhl, 2008; Sakai and Fujita, 2010; Frey et al., 2010; Salerno et al., 2012). To identify PDMDLs in a region, from the view of glacier dynamics, lake type and change, dam characteristics and down-valley status, and guidelines and thresholds for indicating PDMDLs have been comprehensively generalized according to historic MDLOF events (Huggel et al., 2004; McKillop et al., 2007a; Lv et al., 1999). Recently, calculating the breach probability and rating the danger of glacial lakes have been confirmed to be promising approaches, and geostatistics, empirical models, remote sensing and geographic information systems have been put forward to quantify the probability of glacial lake failure in southwestern Pamir, southwestern British Columbia, southeast Tibet and northern Tien Shan (Mergili and Schneider, 2011; McKillop et al., 2007b; Wang et al., 2011; Bolch et al., 2011). However, the available approaches have included limitations when they have been popularized to calculate and rate the breach probability of PDMDLs outside the source region of historic sample MDLOFs, because the guidelines created from the historic sample MDLOFs were characterized by local geographical features (McKillop et al., 2007a). Few methods have been presented to calculate and rate the breach probability of PDMDLs in the Himalayas.

The approach proposed here is intended to allow mathematical estimation of the breach probabilities of PDMDLs over a large area based on remote-sensing data. Unlike previous works, we developed our approach from the view of modeling the triggering chain of a possible breach of a moraine dam, which is assumed to be more suitable for the 
cause-and-effect chain of the breach process of a morainedammed lake. In addition, analyzing the possible breaching modes and qualifying the chain components of a morainedammed lake have not been addressed previously in this detailed way. The reliability analysis of the model results shows that our suggested approach successfully indentifies PDMDLs and rates their level of danger in the Chinese Himalayas and presents criteria for deciding where time- and cost-intensive field studies should be carried out.

There are three main limitations to the presented approach. (1) The geometry parameters of the dam and parent glacier were obtained from the DEM data produced by aerial-survey topographic maps that are not easy to obtain. Freely available DEMs, such as the ASTER GDEM and the SRTM, have been commonly used to measure glacial lakes and shown to be suitable for a first assessment, but they include inaccuracies (Bolch et al., 2011; Frey et al., 2010; Fujita et al., 2008). High-resolution satellite images such as those taken by SPOT5 (2.5-m resolution in the panchromatic band) and IKONOS (1-m resolution in the panchromatic band) may provide alternative data for the aerial-survey DEMs. (2) The criteria of the occurrence probability magnitude were generalized from sample historic breaching of moraine-dammed lakes in the Himalayas, and it would thus be prudent to popularize the criteria for regions outside the Himalayas. On the other hand, the criteria of the occurrence probability magnitude may be adjusted as samples of the breaching of morainedammed lakes are renewed or information is updated. (3) The PDMDLs are distributed at an elevation of $\sim 5200 \mathrm{~m}$ on average, where permafrost develops widely in the Chinese Himalayas. The interactions and chain reactions of permafrost thaw in a lake basin due to atmospheric warming will possibly reduce the stability of the moraine dam and the ice/rock of the lake basin, and are a possible breach mode under warm climatic preconditions. Multi-temporal optical or SAR data can be used to derive surface displacements on creeping and unstable frozen slopes (Kääb, 2008). However, the absence of available data and the limitations of remote-sensing studies make it difficult to obtain the physical characteristics of permafrost, and the stability of the moraine dam and the occurrence of ice avalanches, debris slides, and other permafrost-related activity were not taken into account in our current work.

\section{Conclusions}

With recent global warming, GLOFs are increasingly threatening people and property, and are being intensively studied worldwide. To make first-order estimates of the probability of MDLOF events and prioritize the rate of PDMDLs in the Chinese Himalayas, an objective approach is presented here. In this paper, the region of the Chinese Himalayas was chosen as an area where there have been frequent MDLOFs in recent decades. Using five indexes, 142 potentially dangerous moraine-dammed lakes were first identified in the study area. The breach probabilities of the 142 lakes were then further calculated one-by-one employing decision-making tree methods and data taken from large-scale topographical maps, DEMs, and ASTER images. The results show that the breaching probabilities of the 142 PDMDLs range from 0.037 to 0.345 , and they can be further rated as 43 lakes with very high breaching probabilities (i.e. $P \geq 0.24$ ), 47 with high breaching probabilities $(0.18 \leq P<0.24), 24$ with mid-level breaching probabilities $(0.12 \leq P<0.18), 24$ with low breaching probabilities $(0.06 \leq P<0.12)$, and four with very low breaching probabilities $(P<0.06)$. It is recommended that lakes in the "very high" and "high" categories be considered for further detailed breach risk assessment.

Acknowledgements. We thank Wilfried Haeberli and another anonymous reviewer for their thorough comments which greatly improved the quality of the manuscript. This work was supported by National Science Foundation of China (41271091, 41071044), Innovation Project of the Chinese Academy of Science(KZCX2YW-GJ04), Fund of State Key Laboratory of Frozen Soil Engineering (SKLFSE201102), and the postdoctoral granted financial support from China Postdoctoral Science Foundation (20100480731).

Edited by: J. M. Vilaplana

Reviewed by: W. Haeberli and J. Calvet

\section{References}

Awal, R., Nakagawa, H., Fujita, M., Kawaike, K., Baba, Y., and Zhang H.: Experimental study on glacial lake outburst floods due to waves overtopping and erosion of moraine dam, Annuals of Disas. Prev. Res. Inst., Kyoto Univ., 53B, 583-594, 2010.

Bajracharya, B., Shrestha, A. B., and Rajbhandari, L.: Glacial Lake Outburst Floods in the Sagarmatha Region: Hazard Assessment Using GIS and Hydrodynamic Modeling, Mountain Res. Dev., 27, 336-344, 2007.

Bajracharya, S. R. and Mool, P. K.: Glaciers, glacial lakes and glacial lake outburst floods in the Mount Everest region, Nepal, Ann. Glaciol., 50, 81-86, 2009.

Balmforth, N. J., von Hardenberg, J., Provenzale, A., and Zammett, R. J.: Dam breaking by wave - induced erosional incision, J. Geophys. Res., 113, F01020, doi:10.1029/2007JF000756, 2008.

Balmforth, N. J., von Hardenberg, J., and Zammett, R. J.: Dam breaking seiches, J. Fluid Mech., 628, 1-21, 2009.

Benn, D. I., Benn, T., Hands, K., Gulley, J., Luckman, A., Nicholson, L. I., Quincey, D., Thompson, S., Toumi, R., and Wiseman, S.: Response of debris-covered glaciers in the Mount Everest region to recent warming, and implications for outburst flood hazards, Earth. Sci. Rev., 114, 156-174, doi:10.1016/j.earscirev.2012.03.008, 2012.

Bolch, T., Buchroithner, M. F., Peters, J., Baessler, M., and Bajracharya, S.: Identification of glacier motion and potentially dangerous glacial lakes in the Mt. Everest region/Nepal using spaceborne imagery, Nat. Hazards Earth Syst. Sci., 8, 13291340, doi:10.5194/nhess-8-1329-2008, 2008. 
Bolch, T., Peters, J., Yegorov, A., Pradhan, B., Buchroithner, M., and Blagoveshchensky, V.: Identification of potentially dangerous glacial lakes in the northern Tien Shan, Nat. Hazards, 59, 1691-1714, 2011.

Bolch, T., Kulkarni, A., Kääb, A., Huggel, C., Paul, F., Cogley, J. G., Frey, H., Kargel, J. S., Fujita, K., Scheel, M., Bajracharya, S., and Stoffel, M.: The State and Fate of Himalayan Glaciers, Science, 336, 210-214, 2012.

Carey, M.: Living and dying with glaciers: people's historical vulnerability to avalanches and outburst floods in Peru, Glob. Planet. Change, 47, 122-124, 2005.

Carrivick, L. J.: Application of 2D hydrodynamic modeling to highmagnitude outburst floods: An example from Kverkfjöll Iceland, J. Hydrol., 321, 187-199, 2006.

Cenderelli, A. D. and Wohl, E. E.: Flow hydraulics and geomorphic effects of glacier-lake outburst floods in the mountain Everest region Nepal, Earth Surf. Proc. Land., 28, 385-407, 2003.

Che, T., Jin, R., Li, X., and Wu, L.: Glacial Lakes Variation and the Potentially Dangerous Glacial Lakes in the Pumqu Basin of Tibet during the Last Two Decades, J. Glaciol. Geocryo., 26, 397-402, 2004 (in Chinese with English abstract).

Chen, C., Liu, M., and Zhang Z.: Outburst conditions of morainedammed lakes and their flood estimation headwaters of the Nianchu River, Tibet. J. Glaciol. Geocryo., 18 , 347-352, 1996 (in Chinese with English abstract).

Chen, C., Wang, T., Zhang, Z., and Liu, Z.: Glacial lake outburst floods in upper Nainchu River Basin, Tibet, J. Cold Reg. Eng., 13, 199-212, 1999.

Chen, X., Cui, P., Li, Y., Yang, Z., and Qi, Y.: Changes in glacial lakes and glaciers of post-1986 in the Poiqu River basin, Nyalam, Xizang (Tibet), Geomorphology, 88, 298-311, 2007.

Cheng, Z., Tian, J., Zhang, Z., and Qiang, B.: Debris flow induced by glacial lake in Southeast Tibet, Earth Sci. Front., 16, 207-214, 2009 (in Chinese with English abstract).

Clague, J. J. and Evans, S. G.: A review of catastrophic drainage of moraine-dammed lakes in British Columbia, Quaternary Sci. Rev., 19, 1763-1783, 2000.

Costa, J. E. and Schuster, R. L.: The formation and failure of natural dams, Geol. Soc. AM. Bull., 100, 1054-1068, 1988.

Cui, P., Ma, D., Chen, N., and Jiang, Z.: The initiation, motion and mitigation of debris flow caused by glacier lake outburst, Quaternary Sci., 23, 621-628, 2003 (in Chinese with English abstract).

Dai, F. C. and Lee, C. F.: A spatiotemporal probabilistic modelling of storm-induced shallow landsliding using aerial photographs and logistic regression, Earth Surf. Proc. Land., 28, 527-545, 2003

Frey, H., Haeberli, W., Linsbauer, A., Huggel, C., and Paul, F.: A multi-level strategy for anticipating future glacier lake formation and associated hazard potentials, Nat. Hazards Earth Syst. Sci., 10, 339-352, doi:10.5194/nhess-10-339-2010, 2010.

Fujita, K., Suzuki, R., Nuimura, T., and Sakai, A.: Performance of ASTER and SRTM DEMs, and their potential for assessing glacial lakes in the Lunana region, Bhutan Himalaya, J. Glaciol., 54, 220-228, 2008.

Haeberli, W. and Hoelzle, M.: Application of inventory data foe estimating characteristics of and regional climate-change effects on mountain glaciers: a pilot study with the European Alps, Ann. Glaciol., 21, 206-212, 1995.
Haeberli, W., Clague, J. J., Huggel, C., and Kääb, A.: Hazards from lakes in high-mountain glacier and permafrost regions: Climate change effects and process interactions. Avances de la Geomorphología en España, 2008-2010, XI Reunión Nacional de Geomorphología, Solsona, 439-446, 2010.

Hegglin, E. and Huggel, C.: An integrated assessment of vulnerability to glacier hazards: a case study in the cordillera blanca, Peru, Mountain Res. Dev., 28, 310-317, 2008.

Huggel, C., Kääb, A., Haeberli, W., Teysseire, P., and Paul, F.: Remote sensing based assessment of hazards from glacier lake outbursts: a case study in the Swiss Alps, Can. Geotech. J., 39, 316330, 2002.

Huggel, C., Haeberli, W., Kääb, A.,Bieri, D., and Richardson, S.: An assessment procedure for glacial hazards in the Swiss Alps, Can. Geotech. J., 41, 1068-1083, 2004.

ICIMOD: The Role of the Hindu Kush-Himalayan (HKH) Mountain System in the Context of a Changing Climate: A Panel Discussion, Mountain Res. Dev., 29, 184-187, 2009.

Janský, B., Šobr, M., and Engel, Z.:: Outburst flood hazard: Case studies from the Tien-Shan Mountains, Kyrgyzstan, Limnologica, 40, 358-364, doi:10.1016/j.limno.2009.11.013, 2010.

Jiang, Z., Cui, P., and Jiang, L.: Critical hydrological conditions for overflow burst of moraine lake, Chinese Geogr. Sci., 14, 39-476, 2004.

Kattelmann, R.: Glacial lake outburst floods in the Nepal Himalaya: a manageable hazard?, Nat. Hazards, 28, 145-154, 2003.

Kääb, A.: Remote Sensing of Permafrost-related Problems and Hazards, Permafrost Periglac. Process., 19, 107-136, 2008.

Kershaw, J. A., Clague, J. J., and Evans, S. G.: Geomorphic and sedimentological signature of a two-phase outburst flood from moraine-dammed Queen Bess Lake, British Columbia, Can. Earth Surf. Proc. Land, 30, 1-25, 2005.

Li, D. and You, Y.: Bursting of the Midui moraine lake in Pomi, Xizang, Mountain Res., 10, 219-224, 1992, (in Chinese with English abstract).

Liu, C. and Sharma, C. K.: Report on first expedition to glaciers and glacier lakes in the Pumqu (Arun) and Poiqu (Bhote-SunKosi) River Basin, Xizang (Tibet), China, Beijing, Science Press, 1192, 1988

Lliboutry, L., Morales, A. B., Pautre, A., and Schneider, B.: Glaciological problems set by the control of dangerous lakes in Cordillera Blanca, Peru. I. Historic failures of morainic dams, their causes and prevention, J. Glaciol., 18, 239-254, 1977.

Lv, R., Tang, B., and Li, D.: Debris flow and environment in Tibet, Chengdou, China: Sichuan University Publishing House, 69-105, 1999 (in Chinese).

McKillop, R. J. and Clague, J. J.: A procedure for making objective preliminary assessments of outburst flood hazard from morainedammed lakes in southwestern British Columbia, Nat. Hazards, 41, 131-157, 2007a.

McKillop, R. J. and Clague, J. J.: Statistical, remote sensing-based approach for estimating the probability of catastrophic drainage from moraine-dammed lakes in southwestern British Columbia, Glob. Planet. Change, 56, 153-171, 2007b.

Mergili, M. and Schneider, J. F.: Regional-scale analysis of lake outburst hazards in the southwestern Pamir, Tajikistan, based on remote sensing and GIS, Nat. Hazards Earth Syst. Sci., 11, 14471462, doi:10.5194/nhess-11-1447-2011, 2011. 
Mool, P. K., Bajracharya, S. R., and Joshi, S. P.: Inventory of glaciers, glacial lakes and glacial lake outburst floods, Nepal, ICIMOD, Kathmandu, Nepal, 2001a.

Mool, P. K., Wangda, D., Bajracharya, S. R., Kunzang, K., Gurung, D. R., and Joshi, S. P.: Inventory of glaciers, glacial lakes and glacial lake outburst floods, Bhutan, International Centre for Integrated Mountain Development, Kathmandu, Nepal, 2001b.

Paterson, W. S. B.: The Physics of Glaciers, Oxford: Elsevier Science Ltd, 238-288, 1994.

Peng, X.: Application of risk analysis in China dam safety. Dissertation for Master Degree of Engineering, Nanjing Hydraulic Research Institute, 2003 (in Chinese with English abstract).

Quincey, D. J., Richardson, S. D., Luckman, A., Lucas, R. M., Reynolds, M. J., Hambrey, M. J., and Glasser, N. F.: Early recognition of glacial lake hazards in the Himalaya using remote sensing datasets, Glob. Planet. Change, 56, 137-152, 2007.

Randhawa, S. S., Sood, R. K., Rathore, B. P., and Kulkaeni, A. V.: Moraine-dammed lakes study in the Chennab and the Satluj River Basins using IRS data, J. Indian Soc. Remote Sens., 33, 285-290, 2005.

Reynolds, J. M.: On the formation of supraglacial lakes on debriscovered glaciers, IAHS Publ., 264 (Symposium at Seattle 2000Debris-Covered Glaciers), 153-161, 2000.

Reynolds, J. M., Dolecki, A., and Portocarrero, C.: The construction of a drainage tunnel as part of glacial lake hazard mitigation at Hualan, Cordillera Blanca, Peru, in: Geohazards in Engineering Geology, edited by: Maund, J. G. and Eddleston, M., Geological Society Engineering Geology Special Publication, 15, 41-48, 1998.

Richardson, S. D. and Reynolds, J. M.: An overview of glacial hazards in the Himalayas, Quaternary Int., 65/66, 31-47, 2000.

Röhl, K.: Characteristics and evolution of supraglacial ponds on debris-covered Tasman Glacier, New Zealand, J. Glaciol., 54, 867-880, 2008.

Rushmer, E. L.: Physical-scale modelling of jökulhlaups (glacial outburst floods) with contrasting hydrograph shapes, Earth Surf. Proc. Land, 32, 954-963, 2007.

Sakai, A. and Fujita, K.: Formation conditions of supraglacial lakes on debriscovered glaciers in the Himalaya, J. Glaciol., 56, 177$181,2010$.

Salerno, F., Thakuri, S., D’Agata, C., Smiraglia, C., Manfredi, E. C., Viviano, G., and Tartari, G.: Glacial lake distribution in the Mount Everest region: Uncertainty of measurement and conditions of formation, Glob. Planet. Change, 92-93, 30-39, doi:10.1016/j.gloplacha.2012.04.001, 2012.
Suzuki, R., Fujita, K., and Ageta, Y.: Spatial distribution of thermal properties on debris-covered glaciers in the Himalayas derived from ASTER data, Bull. Glaciol. Res., 24, 13-22, 2007.

Vuichard, D. and Zimmerman, M.: The 1985 catastrophic drainage of a moraine-dammed lake, Khumbu Himal, Nepal: cause and consequences, Mountain Res. Dev., 7, 91-110, 1987.

Vilímek, V., Zapata, M.L., Klimeš, J., Patzelt, Z., and Santillán, N.: Influence of glacial retreat on natural hazards of the Palcacocha Lake area, Peru, Landslides, 2, 107-115, 2005.

Wang, X., Liu, S., Guo, W., and Xu, J.: Assessment and Simulation for Glacier Lake Outburst flood of Longbasaba and Pida Lakes, China, Mountain Res. Dev., 28, 310-317, 2008.

Wang, W., Yao, T., Gao, Y., Yang, X., and Kattel, D. B.: A Firstorder Method to Identify Potentially Dangerous Glacial Lakes in a Region of the Southeastern Tibetan Plateau, Mountain Res. Dev., 31, 122-130, 2011.

Wang, X., Liu, S., Guo, W., Yao, X., Jiang, Z., and Han, Y: Using Remote Sensing Data to Quantify Changes in Glacial Lakes in the Chinese Himalaya, Mountain Res. Dev., 32, 203-212, 2012.

Watanabe, T., Lamsal, D., and Ives, J. D.: Evaluating the growth characteristics of a glacial lake and its degree of danger: Imja Glacier, Khumbu Himal, Nepal, Norsk Geografisk Tidsskrift, Norwegian J. Geogr., 63, 255-267, 2009.

$\mathrm{Xu}, \mathrm{D}$.: Characteristics of debris flow caused by outburst of glacier lake in Boqu River, Xizang, China, GeoJournal, 17, 569-580, 1988.

Xu, D. and Feng, Q.: Dangerous glacial lake and outburst features in Xizang Himalaya, Acta Geogr. Sin., 44, 343-352, 1989 (in Chinese with English abstract).

Yao, X., Liu S., Sun, M., Wei, J., and Guo, W.: Volume calculation and analysis of the changes in moraine-dammed lakes in the North Himalayas: a case study of Longbasaba Lake, J. Glaciol., 58, doi:10.3189/2012JoG11J048, 2012.

Yesenov, U. Y. and Degovets, A. S.: Catastrophic mudflow on the Bol'shaya Almatinka River in 1977, Soviet Hydrology, Selected Papers, 18, 158-160, 1979.

Yue, Z., Cao, Z., Li, X., and Che, T.: Two-dimensional coupled mathematical modeling of fluvial processes with intense sediment transport and rapid bed evolution, Sci. China Ser. G, 51, 1427-1438, 2008. 